\title{
OBJEKTNO USMERJENA ANALIZA PODATKOV DALJINSKEGA ZAZNAVANJA
}

\author{
OBJECT-BASED IMAGE ANALYSIS OF REMOTE SENSING DATA
}

\author{
Tatjana Veljanovski, Urša Kanjir, Krištof Oštir
}

UDK: 528.8/.9:912

\section{IZVLEČEK}

Na področju daljinskega zaznavanja se razvijajo različne metode in tehnologije za brezkontaktno in stroškovno učinkovito izdelavo kart pokrovnosti/rabe tal na velikih območjih ter drugih tematskih kart. Osrednjega pomena za zadostno razpoložljivost in zanesljivost takšnih kart za raziskave zemeljskega površja je razvoj učinkovitih postopkov analize in klasifikacije posnetkov. Za klasifikacijo satelitskih posnetkov nizke in srednje ločljivosti (njihova prostorska ločljivost je kvečjemu primerljiva z velikostjo geografskih objektov) zadostuje uporaba pikselsko usmerjene klasifikacije, pri kateri posamični piksel razvrstimo v najprimernejši razred na podlagi njegovih spektralnih lastnosti.

Ko povečujemo prostorsko ločljivost posnetkov, pikselska klasifikacija ni več učinkovita. Bistveno se namreč spremeni razmerje med velikostjo piksla na eni ter razsežnostjo in detajlom opazovanih elementov (objektov) geografske stvarnosti na drugi strani. V zadnjem desetletju se zato vse bolj uveljavlja objektno usmerjen pristop obdelave podob. Ta združuje segmentacijo, ki je temeljna faza za razmejevanje geografskih elementov, in klasifikacijo, kije semantično (kontekstualno) podprta. Segmentacija razdeli podobo na homogene skupine pikslov (segmente), semantična klasifikacija pa jih nato razvršča v razrede na podlagi njihovih spektralnih, geometričnih, teksturnih in drugih lastnosti. Namen prispevka je predstaviti teoretično utemeljitev in metodologijo objektno usmerjene obdelave $v$ daljinskem zaznavanju, podati pregled stanja na področju ter opozoriti na nekatere omejitve tehničnih rešitev.

\section{KLJUČNE BESEDE}

daljinsko zaznavanje, objektno usmerjena analiza podob, segmentacija, objektna klasifikacija, semantična klasifikacija
Klasifikacija prispevka po COBISS-u: 1.02

\begin{abstract}
Remote sensing has developed various methods and technologies for contactless and cost-effective mapping of large area land cover/land use maps and other thematic maps. The key factor for the availability and reliability of these maps for use in Earth sciences is the development of effective procedures for satellite data analysis and classification. The most appropriate approach for classifying low and medium resolution satellite images (pixel size is coarser than, or at best similar to, the size of geographical objects) is pixelbased classification in which an individual pixel is classified into the closest class based on its spectral similarity.
\end{abstract}

With increasing spatial resolution, pixel-based classification methods became less effective, since the relationship between the pixel size and the dimension of the observed objects on the Earth's surface has changed significantly. Therefore object-oriented classification has become increasingly popular over the past decade. This combines segmentation (which is a fundamental phase of the approach) and contextual classification. Segmentation divides the image into homogeneous pixel groups (segments), which are during the semantic classification process - arranged into classes based on their spectral, geometric, textural and other features during. The intent of this paper is to present the theoretical argumentation and methodology of object-based image analysis of remote sensing data, provide an overview of the field and point out certain restrictions as regards the current operational solutions.

\section{KEY WORDS}

remote sensing, object-based image analysis, segmentation, object-based classification, semantic classification 


\section{UVOD}

Satelitski posnetki zagotavljajo različne podatke o zemeljskem površju, njegovih lastnostih in so vir pridobivanja posodobljenih informacij o stanju površja. Informacija (izdelek), ki jo želimo pridobiti iz satelitskega posnetka, je tematska karta, najpogosteje karta pokrovnosti/rabe tal na velikih območjih, narašča pa tudi zanimanje za karte sprememb in biofizikalnih lastnosti površja. Ključni dejavnik za kakovost tematske informacije, pridobljene s satelitskega posnetka, so zanesljivi postopki klasifikacije posnetkov. O pomenu teh postopkov zgodovinsko in razvojno priča veliko raziskav (Schowengerdt, 2007; Oštir, 2006).

Glavni namen klasifikacije je razpoznavanje in poimenovanje elementov (geografskih objektov in pojavov) na zemeljskem površju (slika 1). Pri vizualni (ročni) interpretaciji (slika 1a) poskuša operater določiti razrede rabe tal z iskanjem zaključenih skupin pikslov. Digitalna (samodejna) klasifikacija razrede določi z upoštevanjem spektralnih in/ali geometričnih, teksturnih, kontekstualnih, časovnih informacij ter matematičnim (statističnim) razvrščanjem $\mathrm{v}$ razrede (Navulur, 2007; Oštir, 2006). Digitalna pikselska klasifikacija (slika 1b) razvršča vsak piksel posebej v najustreznejši tematski razred na podlagi spektralnega podpisa piksla. Digitalna objektna klasifikacija (slika 1c) najprej prepozna območja s skupnimi strukturnimi lastnostmi, nato jih ob upoštevanju več atributov razvršča v ustrezne tematske razrede. Objektno usmerjena klasifikacija tako združuje prednosti vizualne interpretacije podob in pikselske klasifikacije.

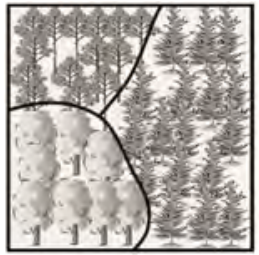

a)

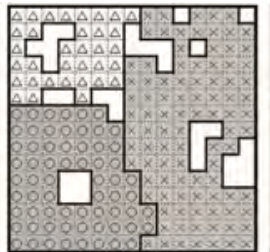

b)

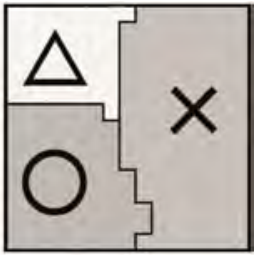

c)

Slika 1: Različni pristopi klasifikacije na primeru vegetacije (Blaschke et al., 2008): a) vizualna interpretacija, b) pikselska klasifikacija in c) objektna klasifikacija.

Na satelitskih posnetkih se zapisujejo odbojnosti površja v obliki digitalnih vrednosti, ki so predstavljene kot matrike pikslov. Zato so prvotne digitalne klasifikacije satelitskih posnetkov izhajale iz pikselsko usmerjenega pristopa. Ta pristop se osredotoča na posamezen piksel, ki v splošnem ne predstavlja enote geografske stvarnosti (geografskega objekta), zanemarjen je tudi pomen elementov okolice (okoliških pikslov).

V zadnjem desetletju se je $\mathrm{z}$ razvojem satelitskih posnetkov s prostorsko ločljivostjo pod $1 \mathrm{~m}$ precej spremenilo razmerje med velikostjo piksla in razsežnostjo opazovanih objektov: velikost piksla je bistveno manjša od povprečne velikosti opazovanega predmeta (slika 2). Na visokoločljivih posnetkih tradicionalne pikselsko naravnane klasifikacijske metode niso učinkovite, saj je zanje na posnetkih preveč podrobnosti. Pozornost je bila tako preusmerjena s posameznih pikslov na njihovo skupinsko reprezentacijo, objekte, kot vhodne podatke za analize. Objektno usmerjen pristop je omogočil, da so se pri postopku razločevanja in prepoznavanja geografskih objektov uporabile prednosti več področij: strojno prepoznavanje vzorcev, analiza atributov vektorjev 
in predvsem raznovrstne lastnosti daljinsko zaznanih podatkov - spektralne, geometrične, kontekstualne, morfološke in časovne (Navulur, 2007). Vodilno načelo objektno usmerjene klasifikacije je (Blaschke et al., 2008): zapleteno in heterogeno vsebino o površju Zemlje, upodobljeno na satelitskih posnetkih, je treba opisati na najboljši mogoč način, vsaka opisana vsebina pa mora biti čim bolj intuitivno razumljiva uporabnikom.

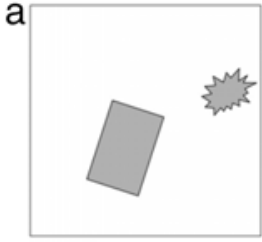

$20 \mathrm{~m}$ piksel

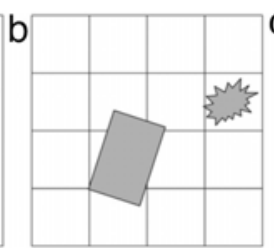

$5 \mathrm{~m}$ piksel

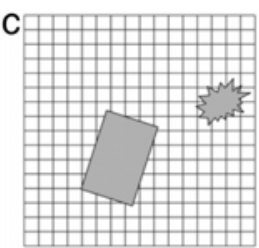

$1.25 \mathrm{~m}$ piksel

Slika 2: Razmerje med velikostjo geografskega objekta in prostorsko ločljivostjo (Blaschke, 2010): a) nizka ločljivost: piksli so znatno večji od objektov, potrebna je podpikselska obravnava; b) srednja ločljivost: velikost piksla je primerljiva z velikostjo objekta, ustrezna je pikselska obravnava in c) visoka ločljivost: piksli so občutno manjši od objektov, potrebna je regionalizacija pikslov $v$ skupine in nato v objekte.

V drugem poglavju podajamo zgodovinski pregled prehoda s pikselske na objektno usmerjeno analizo satelitskih posnetkov in utemeljitve za ta prehod. Tretje poglavje opredeljuje in pojasnjuje izraze v objektno usmerjeni analizi daljinsko zaznanih podatkov. V četrtem poglavju predstavljamo metodologijo, pri čemer so opisani koraki obdelave ter povzete prednosti in omejitve objektno usmerjene obdelave. V petem poglavju so orisane značilne uporabe objektne klasifikacije. V razpravi namenjamo poudarek vrednotenju objektno usmerjene metodologije in potencialnim smerem razvoja, pri čemer se naslanjamo na objavljene in lastne izkušnje.

\section{UMESTITEV OBJEKTNO USMERJENE ANALIZE PODOB}

\subsection{Pikselsko usmerjena analiza satelitskih posnetkov}

Daljinsko zaznavanje omogoča pridobivanje informacij o površju Zemlje v vidnem, infrardečem in mikrovalovnem delu spektra. Prvi senzorji na satelitskih sistemih so bili večspektralni, s čimer so kompenzirali nižjo prostorsko ločljivost podatkov. Ker različni tipi površja različno odbijajo energijo, se v spektralnem območju različno izražajo, zaradi česar jih lahko analiziramo s spektrometričnimi postopki. V takratnih tehnoloških razmerah (70. leta prejšnjega stoletja) je bilo najbolj samoumevno obravnavati posamezen piksel z namiznim spektrometrom in tako je bil piksel od vsega začetka osnovna enota za postopke obdelave v daljinskem zaznavanju (Schowengerdt, 2007; Liang, 2004). Obenem so razvili prve digitalne postopke združevanja pikslov v razrede (klasifikacija), s čimer so premostili manjkajočo obravnavo prostorskih vzorcev. Tako se je pikselsko usmerjena obravnava $\mathrm{v}$ analizah satelitskih posnetkov utrdila kot splošna praksa. Tedaj je tudi obveljalo, da je interpretacija satelitskih posnetkov predvsem $\mathrm{v}$ domeni človekovih zmožnosti (Oštir, 2006).

Pikselsko usmerjene metode klasifikacije so danes že podrobno proučene in detajlno matematično izpeljane (glej: Schowengerdt, 2007; Oštir, 2006; Lillesand et al., 2004; Albertz; 2001; Richards 
in Jia, 1999). Pikselsko klasifikacijo omogoča spektralni podpis, to je značilen način odboja elektromagnetnega valovanja od površja Zemlje v odvisnosti od valovne dolžine (Oštir, 2006). Večina metod temelji na analizah gruč (angl. cluster analysis). Razvila sta se dva pristopa: nenadzorovana klasifikacija, pri kateri algoritem sam poišče najustreznejše kandidate pikslov (na podlagi vnaprej določenega števila razredov) ter jih razvršča po kriteriju statistične najbližje pripadnosti, ter nadzorovana klasifikacija, ki poteka na podlagi učnih vzorcev in referenčnih podatkov ter statističnega razvrščanja $\mathrm{v}$ razrede.

Vsa naslednja desetletja so se raziskave usmerjale v postopke digitalne obdelave podob (radiometrični in geometrični popravki, klasifikacija, primerjava podob). Glavna težnja je bila priprava samodejnih postopkov obdelave in analize posnetkov, da bi daljinsko zaznavanje lahko približali širšemu krogu uporabnikov (Oštir, 2006). Dejstvo, da posamezni piksli pravzaprav ne predstavljajo nikakršne enote geografske stvarnosti, je bilo zanemarjeno skoraj tri desetletja, in sicer tako zaradi intenzivnega razvoja pikselsko usmerjenih algoritmov obdelave podob kot zaradi omejitev strojne in programske opreme.

\subsection{Prehod s pikselske na objektno usmerjeno analizo satelitskih posnetkov}

S pojavom visokoločljivih satelitskih posnetkov je postala pikselsko usmerjena obdelava posnetkov težavnejša. Ker je bila razvita za posnetke do srednje prostorske ločljivosti (10-100 m), je bila za obdelavo visokoločljivih posnetkov manj učinkovita in časovno zelo potratna. Zahteva po učinkovitejših rezultatih v študijah sprememb na površju Zemlje je dokončno opozorila na nujno potrebo po drugačnem pristopu (Blaschke in Strobl, 2001). Neučinkovitost je bila tudi posledica dejstva, da je delež končne interpretacije več podob sprememb (kategorizacija prostorskih vzorcev identificiranih sprememb) odvisen od človeškega dejavnika ter še zdaleč ni časovno in vsebinsko zanemarljiv.

Blaschke in Strobl sta v svoji objavi (2001) opozorila na težavo osredotočenosti statistične analize izključno na posamezne piksle namesto na prostorske vzorce, ki jih ti ustvarjajo skupaj. Čeprav ta problematika ni bila nova (Hall et al., 1995; Cracknell, 1998), je postalo očitno, da se vse več študij in aplikacij zateka k vpeljavi segmentacije podobe. Segmentacija podob, sprva ročna (digitalizacija), nato pa tudi digitalna, se v osemdesetih in devetdesetih letih uporablja v prostorskih aplikacijah z daljinsko zaznanimi podatki, vendar le v manjši meri (Haralick in Shapiro, 1985; Pal in Pal, 1993).

Ključni motivi za prehod s pikselskega na objektno usmerjen pristop na področju daljinskega zaznavanja so bili: (1) zahteva po boljši interpretativni vrednosti daljinsko zaznanih podatkov $\mathrm{v}$ različnih aplikacijah (predvsem pri časovnih primerjavah in manifestacijah uporabe daljinsko zaznanih podatkov za načrtovanje), (2) naraščanje razpoložljivosti satelitskih posnetkov visoke ločljivosti, pri čemer lahko opazujemo bistveno bolj podrobne predmete na površju (narašča zanimanje za kontekstualno vrednotenje vsebine posnetkov), ter (3) višja raven razvoja tehnološke opreme in algoritmov za obravnavo podatkov daljinskega zaznavanja (dostopnost širšemu krogu uporabnikov; prenos GIS objektno usmerjenih prostorskih analiz na področje posebnosti rastrskih daljinsko zaznanih podatkov). 
Tako je (šele) v zadnjem desetletju, hkrati z razvojem bolj kompleksnih algoritmov obdelave ter integracijo daljinsko zaznanih podatkov v geografske informacijske sisteme, nastopil ključen premik na področju obravnave osnovne enote daljinsko zaznanih podatkov. Osnovna enota je - namesto piksla - postal objekt.

\subsection{Objektno usmerjene analize v daljinskem zaznavanju}

Objektno usmerjene analize slik so se konec prejšnjega stoletja zelo razmahnile na področju računalniškega vida ter bio- in nevromedicine, predvsem na račun vse bolj učinkovite uporabe tehnik, ki delujejo v območju intenzitetnih vrednosti pikslov (Gonzales in Woods, 2002). Prenos teh algoritmov na področje daljinskega zaznavanja sprva ni bil najbolj uspešen, metodologija je bila v rezultatih manj učinkovita. Razlogi so trije. Prvič, satelitski posnetek pokriva znatno večje območje v naravi kot slike, na katerih so bili razviti algoritmi računalniškega vida. Drugič, objekti, ki so predmet zanimanja na satelitskih posnetkih, večinoma nimajo »tipičnih « oblik, vselej pa tudi ne ostrih in nedvoumnih meja v prostoru. Pri danem objektnem tipu (npr. zgradbe, gozd, voda) se lahko spreminjajo kraj pojavljanja, velikost, oblika, spektralni prostor pojavljanja. Zaradi tega je nabor objektov zelo heterogen in zato razmeroma neobvladljiv. In tretjič, posnetki so praviloma večspektralne podobe, zajete ob različnih časih in v različnih prostorskih ločljivostih, kar določa tudi način in vsebino obravnave »iskanih « objektov (Schiewe et al., 2001). Naštete značilnosti so narekovale obravnavo in razvoj algoritmov, ki sta prilagojena značilnostim satelitskih posnetkov (Castilla in Hay, 2008; Blaschke et al., 2008; Johansen et al., 2011).

Medtem ko so v geografskih informacijskih sistemih ter na področju digitalne obdelave slik objektno usmerjene analize podatkov poznane že nekaj časa, je v daljinskem zaznavanju od začetka razvoja tehnologije do devetdesetih let mogoče zaslediti posamične pobude in poskuse objektno usmerjenega pristopa (glej Horowitz et al., 1975; Ketting in Landgrebe, 1976; Mason et al., 1988; Beaudoin et al., 1990; Quegan et al., 1992). V navedenih študijah so uporabljali ročno segmentacijo podobe in izračunali nekaj osnovne statistike za segmente. Nanašala se je predvsem na opise spektralnih lastnosti za posamezen spektralni kanal (srednja vrednost, minimum, maksimum, standardni odklon). To pridobljeno prednost so še vedno oteževale radiometrične lastnosti posnetkov (radiometrična variabilnost lastnosti segmentov), predvsem pa slaba programska podpora za obdelavo. Šele konec devetdesetih let prejšnjega stoletja, ko je bilo mogoče (zaradi večje ločljivosti in posledično večjega števila pikslov v posameznem segmentu) segmentom pripisati tudi nekatere geometrične, teksturne, konceptualne in druge lastnosti ter ves nabor atributov tudi obdelovati, je nastopil pomemben premik na področju objektno usmerjene pretvorbe satelitske podobe $\mathrm{v}$ tematsko karto (Johansen et al., 2011).

Objektno usmerjene analize v daljinskem zaznavanju so doživele razmah, ko je leta 2000 prišel na trg program eCognition, prvi komercialni izdelek, ki je ponudil kakovostno obravnavo objektno usmerjenih analiz in je znal uporabiti tudi večspektralne lastnosti satelitskih posnetkov. Nekaj let kasneje so sledili programski moduli, vključeni v programe Erdas (modul Objective), ArcGIS (Feature Analyst) in ENVI (Feature Extraction v ENVI Zoom). Ker je področje navkljub programski podpori zelo kompleksno, so raziskovalci leta 2006 dali pobudo, da si tudi prek 
bienalnih znanstvenih srečanj prizadevajo za utrditev nove znanstvene discipline, imenovane GEOBIA (Geo-Object-Based Image Analysis; Lang et al., 2006; Blaschke et al., 2008; Addink in Van Coillie, 2010). V tej novi podveji geografskih informacijskih sistemov se kot osnovna enota uporabljajo homogena območja, pridobljena iz daljinsko zaznanih posnetkov. Temeljni cilj pa je podpreti računalniške (samodejne) postopke za razpoznavanje homogenih območij iz daljinsko zaznanih podatkov ter njihovo celostno analizo z vso teoretično in konceptualno podporo (GEOBIA, 2011; Hay in Castilla, 2006).

Danes je objektno usmerjena analiza na prostorskih podatkih že dozorela in velja splošno soglasje, da objektna analiza podob temelji na konceptih segmentacije, odkrivanja robov, prepoznavanja in razvrščanja objektov (klasifikacije), ki so se v obdelavi podob daljinskega zaznavanja uporabljali že desetletja (Johansen et al., 2011).

\section{OPREDELITEV IZRAZOV IN POJMOV}

V tem poglavju so opredeljeni in razloženi izrazi, ki se nanašajo na objektno usmerjene analize (angl. object-based image analysis) na podatkih daljinskega zaznavanja, ki jih uporabljamo v članku.

Začnimo s tem, kateri izraz je primernejši za prestavitev angleškega izraza »object«. Je to slovenski »predmet« ali »objekt« oziroma »predmetno《 ali »objektno«? Slovar slovenskega knjižnega jezika objekt opredeljuje predvsem kot »nekaj, kar je zgrajeno, narejeno za opravljanje določene dejavnosti«, in nato kot "pojem, stvar, na katerega se nanaša dejanje«. Na drugi strani predmet, ki je v slovarju opredeljen kot »kar obstaja neodvisno od človekove zavesti, mišljenja in je zaznavno s čuti, umom, zlasti kot celota kakih lastnosti«, bolje odraža naravo elementov neantropogene stvarnosti. Na ravni individualne zaznave prostora gradnike stvarnega sveta, ki nas obdaja, imenujemo stvari in predmeti (obkrožajo nas predmeti, kot so miza, vrč, omara), kadar so v naši neposredni bližini in omejene velikosti, razsežnosti. Za bolj oddaljene in obsežnejše elemente stvarnega sveta pa takšno jezikovno sklepanje ne velja več (gozd je stvar, stežka pa mu bomo rekli predmet). Pri prevajanju angleškega izraza »object« zato ne moramo izhajati samo iz jezikoslovne analogije, temveč bolj iz pomena, ki ga izraz ima v angleščini (Helena Dobrovoljc, osebna komunikacija). Predmeti so konkretno oprijemljive stvari, objekt pa ima širše pomensko polje od predmeta. Poleg tega je objekt lahko vse, kar ni subjekt. Pri opredeljevanju izrazov v slovenščini je zato treba iskati ustrezne pojmovne in postopkovne izraze angleškim originalom.

Prostor je objektivna geografska danost, fizično okolje, naša trirazsežna fizična stvarnost, v kateri so osnovni elementi proučevanja pojavi, njihova struktura, stanje, namembnost ter medsebojne zveze in razvojne težnje. Pojem geografske stvarnosti je razmeroma nesporen, različna strokovna področja pa vendarle različno poimenujejo in opredeljujejo vlogo in modeliranje gradnikov geografske stvarnosti v bazah podatkov - geografskih entitet (elementi, strukture, predmeti, objekti in pojavi). V geografiji in kartografiji se pri proučevanju površja Zemlje izraza geografska entiteta (tudi prvina) in topografski objekt (preglednica 1) uporabljata kot sopomenki (GTM, 2005). Ločiti pa ju je mogoče tako, da se pridevnik topografski pretežno uporablja pri večjih podrobnostih (ali merilih), geografski pri manjših, ali pa da se geografski nanaša na opis realnosti, topografski pa 
na vsebino (topografske) baze ali (topografske) karte (Dušan Petrovič, osebna komunikacija). V okolju geografskih informacijskih sistemov (GIS) se geografska entiteta praviloma nanaša na opis realnosti, geografski objekt pa na predstavitev entitete v bazi podatkov (Šumrada, 2005).

Način poimenovanja je torej pogosto vezan na skupino dejavnikov obravnavanja: predmet (in prostorska razsežnost) proučevanja, inštrument opazovanja ter medij in način, v katerem in kako opravljamo analize.

Objektno usmerjene analize, ki jih obravnavamo v prispevku, izhajajo iz lastnosti opazovanja geografske stvarnosti na posnetkih in iz njihove obdelave z geografskimi informacijskimi sistemi. Posnetki upodabljajo površje Zemlje (geografsko stvarnost) kot dvorazsežno položajno matriko pikslov s pripadajočimi spektralnimi atributi. Geografske entitete, ki jih na posnetkih opazujemo, želimo opisati (kartirati), zato gre za pomensko enake ali vsaj sorodne strukture, objekte in pojave, kot jih kartiramo na tematskih, pogojno tudi topografskih kartah. Geografski objekt (angl. geographical object), izraz, ki se široko uporablja v objektno usmerjenih analizah (GEOBIA, 2011), se torej po pomenu ne razlikuje od izraza topografski objekt. Opredelitev osnovnih izrazov in izrazov v objektno usmerjeni obdelavi (klasifikaciji) daljinsko zaznanih podatkov je podana $\mathrm{v}$ preglednici 1 .

Pri objektno usmerjenih analizah imamo torej opravka z dvema pojmoma objektov - objekti na posnetku (to so segmenti, ki so že klasificirani v objekte, razrede) ter geografskimi objekti (to so geografske entitete, topografski objekti). Geografski objekti so resnični objekti in pojavi na zemeljski površini, so elementi geografske stvarnosti. Objekti na posnetku so omejena območja na podobi, ustvarjena v procesu segmentacije in klasifikacije, $\mathrm{z}$ določeno prostorsko, spektralno in teksturno značilnostjo. So notranje skladni v izbranih lastnostih in se razlikujejo od svoje okolice. Objekti na posnetkih (sami ali v skupinah) so v različnih merah (stopnjah) poenostavljen prikaz geografskih (topografskih) objektov in pojavov v naravi. Posamezni objekti (npr. makadamska cesta 1, makadamska cesta 2) pripadajo danemu objektnemu razredu/tipu (makadamske ceste) in nadalje objektni skupini (ceste) ter objektnemu področju (prometnice). Podrazredi in nadrazredi objektnih tipov predstavljajo hierarhično ureditev razredov in njihovih lastnosti (atributi, relacije) v objektnem katalogu. Pri objektni klasifikaciji posnetkov je vsebina kataloga odvisna od namena naloge in uporabljenega postopka, smiselno pa je, da se upoštevata splošna shema in poimenovanje objektnih tipov, ki se uporabljata $\mathrm{v}$ kartografiji (tematski in topografski).

\begin{tabular}{|l|l|}
\hline $\begin{array}{l}\text { Geografska } \\
\text { entiteta }\end{array}$ & $\begin{array}{l}\text { angl. geographical entity } \\
\text { Geografske entitete so gradniki našega (širšega) stvarnega sveta, ki imajo (Šumrada, 2005) lastno } \\
\text { identiteto in pomembne značilnosti. So resnični objekti in pojavi na Zemeljski površini, ki niso naprej } \\
\text { deljivi na pojave istega tipa. So elementi geografske stvarnosti. Topografski objekt na površini Zemlje. } \\
\text { Tudi: geografski objekt (GTS, 2005). Se nanaša na opis realnosti. }\end{array}$ \\
\hline $\begin{array}{l}\text { Geografski } \\
\text { objekt }\end{array}$ & $\begin{array}{l}\text { angl. geographical object } \\
\text { Predstavitev geografske entitete v zbirki podatkov (Šumrada, 2005). V objektno usmerjeni analizi } \\
\text { posnetkov sopomenka za geografsko entiteto. }\end{array}$ \\
\hline
\end{tabular}


Topografski angl. topographical object, geographical object

objekt

Objekt, del Zemljinega površja, drugega planeta ali naravnega satelita z razpoznavno identiteto. Tudi: topografska entiteta (GTS, 2005). Se pogosto nanaša na vsebino topografske baze ali karte (Dušan Petrovič, os. kom.).

Objektno angl. object-based analysis, object-oriented analysis

usmerjena

analiza,

obdelava

Niz postopkov, pri katerem se analiza vsebine podobe (satelitski, zračni posnetki) nanaša na razčlenjevanje (segmentacijo), določitev (klasifikacijo), vrednotenje (oceno natančnosti in poklasifikacijo) in analizo (npr. spremembe, primerjave, kartiranje) pomensko razumljivih prostorskih enot (homogenih območij, struktur, geografskih objektov in pojavov) in ne na analizo posameznih pikslov.

Segment angl. segment

Predstavlja strukturni oris geografske entitete (pojava, objekta) v zbirki podatkov glede na lastnosti, upodobljene na posnetku. Je vsebinsko homogeno in zaključeno, diskretno omejeno območje na podobi. Je vektorski podatek, ki opredeljuje območje računanja atributov.

Atributi angl. attributes, object attributes

Opisujejo lastnosti segmenta ter služijo za opredelitev in klasifikacijo v izbrani objekt ali objektni (klasifikacijski) razred. Poznamo: spektralne, geometrične in strukturne, teksturne, časovne in druge atribute.

Objekt (na angl. object

posnetku)

Je posamezen primer enega ali več ustrezno klasificiranih segmentov glede na njihove skupne značilnosti in relacije. Vsak objekt pripada nekemu (klasifikacijskemu) razredu ali objektnemu tipu. Je predstavitev geografske entitete v zbirki podatkov (Šumrada, 2005).

Objektni angl. object class, thematic class

razred (tip)

Je tematska skupina ali kategorija, ki združuje istovrstne objekte (npr. makadamske ceste). Je rezultat klasifikacije posnetka, zato pogosto vključuje elemente rabe/pokrovnosti tal. Ustreza objektnemu tipu v kartografiji (Dušan Petrovič, os. kom.). Ti so lahko nadalje združeni v objektne skupine in enega ali več objektnih področij (odvisno od namena naloge).

\begin{tabular}{|l|l|}
\hline $\begin{array}{l}\text { Objektna } \\
\text { skupina }\end{array}$ & Združuje sorodne objektne razrede/tipe (npr. ceste). Je nadrazred objektnih tipov. \\
\hline $\begin{array}{l}\text { Objektno } \\
\text { področje }\end{array}$ & Je najvišja raven v hierarhiji objektnega kataloga (npr. prometnice, vodovje, relief, stavbe). \\
\hline $\begin{array}{l}\text { Objektni } \\
\text { katalog }\end{array}$ & $\begin{array}{l}\text { Je seznam, ki vsebuje opredelitve in razvrstitve objektnih razredov/tipov in njihovih lastnosti (atributov) } \\
\text { ter relacij med objekti in pojavi. Podrazredi in nadrazredi (objektni tipi) predstavljajo hierarhijo razredov, } \\
\text { ki se izvede z načelom dedovanja med razredi (Šmrada, 2005). }\end{array}$ \\
\hline $\begin{array}{l}\text { Objektno } \\
\text { usmerjena } \\
\text { klasifikacija }\end{array}$ & $\begin{array}{l}\text { angl. object-based classification } \\
\text { Postopek klasifikacije podob z upoštevanjem semantičnih informacij, ki niso prisotne v posameznem } \\
\text { pikslu. Pri tem prepoznavamo objekte in razmerja med njimi (Oštir, 2006). Je način organizacije } \\
\text { obdelave podob, ki omogoča razvrščanje in združevanje segmentov v objekte in/ali v objektne razrede/ } \\
\text { tipe glede na njihove skupne značilnosti in opredeljen semantični model. } \\
\text { Krajše tudi: objektna klasifikacija, semantična klasifikacija, kontekstualna klasifikacija. }\end{array}$ \\
\hline $\begin{array}{l}\text { Semantično } \\
\text { modeliranje }\end{array}$ & $\begin{array}{l}\text { angl. semantic modelling } \\
\text { Odraža konceptualno (pojmovno) modeliranje, to je (Šumrada, 2005) potek zaznave, interpretacije } \\
\text { in poenostavitve stvarnosti v ustrezen pojmovni model za določeno uporabo. }\end{array}$ \\
\hline
\end{tabular}

Preglednica 1: Opredelitev in pomen izrazov v objektno usmerjeni obdelavi podatkov daljinskega zaznavanja. 


\section{METODOLOGIJA OBJEKTNO USMERJENE ANALIZE PODOB}

Pri objektno usmerjeni analizi v daljinskem zaznavanju se kot osnovna enota uporabljajo homogena območja (segmenti), pridobljeni iz posnetkov. Pri tem se združujejo različni postopki za pridobitev segmentov in njihovih lastnosti (atributov), za analize teh segmentov, za razvrščanje segmentov v razrede ali objekte (klasifikacija), za preverjanje in odpravljanje napak (poklasifikacija) ter nadaljnjo obdelavo (npr. časovne primerjave).

\subsection{Postopek objektne klasifikacije}

Postopek objektne klasifikacije je sestavljen iz treh faz obdelave (slika 3):

- segmentacija in izračun spektralnih, geometričnih, teksturnih, konceptualnih, časovnih atributov,

- objektna (semantična) klasifikacija,

- poklasifikacija (preverjanje, popravljanje) in ovrednotenje rezultatov.

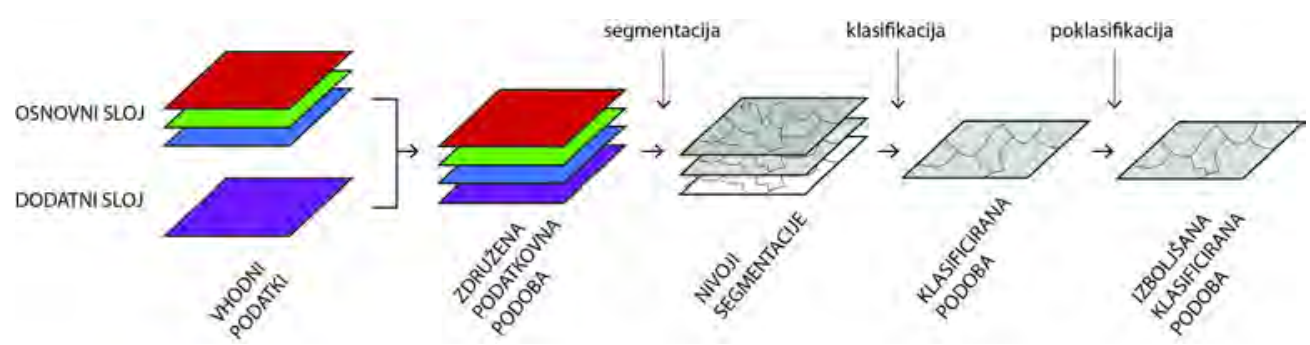

Slika 3: Postopek objektno usmerjene klasifikacije na podatkih daljinskega zaznavanja.

Osnovni vhodni sloj je večspektralna satelitska ali zračna podoba. Glede na namen objektne analize lahko v postopek vključimo tudi druge, dodatne sloje, zaradi katerih je učni proces razvrščanja segmentov v objektne tipe natančneje definiran. Dodatni ali pomožni sloj je lahko tematska maska, s katero vključimo ali izključimo izbrana območja in/ali sloj geomorfoloških lastnosti (naklon,višina) ali drugih lastnosti površja.

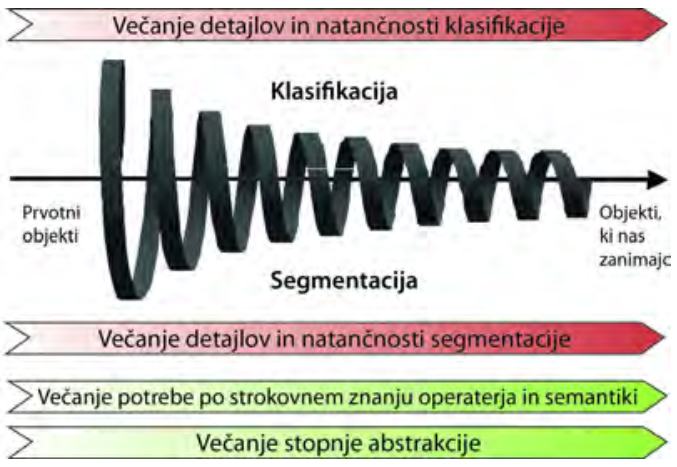

Slika 4: Splošne značilnosti postopka objektne klasifikacije (Blaschke et al., 2008). 
Segmenti, ustvarjeni v prvem koraku objektne klasifikacije, vplivajo na končni rezultat klasifikacije (Blaschke et al., 2008). Segmentacija in klasifikacija sta v vzročni soodvisnosti, podrobnosti in napake prve se prenašajo na drugo. Tako so lastnosti in kakovost atributov, ki jih kasneje uporabljamo za ocenjevanje in razvrščanje objektov, neposredno odvisne od načina tvorjenja segmentov. Lastnosti objektno usmerjenega pristopa lahko ponazorimo s spiralo, pri čemer vsak korak temelji na rezultatih prejšnjih korakov (slika 4).

\subsubsection{Segmentacija}

Najtežja naloga objektno usmerjenih analiz je zadovoljivo izvesti segmentacijo - z enim postopkom doseči ravno pravo raven predstavitve številnih, po velikosti in lastnostih različnih, prostorskih enot oziroma objektov (Blaschke et al., 2008; Nussbaum in Menz, 2008). Pri tem gre za razmejevanje posnetka $\mathrm{v}$ homogene segmente $\mathrm{z}$ združevanjem sosednjih pikslov s podobnimi atributnimi vrednostmi (intenziteta, tekstura, barva itd.) na podlagi več kriterijev homogenosti (ENVI, 2004). Tako ustvarjeni segmenti praviloma še ne predstavljajo realnih objektov na posnetku, ampak njihove dele. $Z$ optimalno izbiro parametrov segmentacije se pričakuje, da se podoba razdeli na semantično pomembne segmente, ki bodo lahko prepoznavni v naslednjih korakih obdelave.

Proces segmentacije se uporablja v več vedah (medicini, nevroinformatiki, telekomunikacijah), zato so na voljo številne tehnike segmentiranja. Pri večini teh algoritmov niso upoštevane večspektralne in prostorske informacije, zato za klasifikacijo daljinsko zaznanih podob niso vselej primerni. Implementirana sta večinoma dva razreda algoritmov (Gao et al., 2007; Nussbaum in Menz, 2008). Prvi izhaja iz določitve robov območij (angl. edge-based), drugi iz razraščanja območja (angl. region growing), lahko pa gre tudi za kombinacijo obeh (Schiewe, 2002). Katera tehnika je boljša in učinkovitejša, je odvisno od podatkov (tudi lastnosti območja), nastavitve parametrov in namena analize. Dobra izbira je večstopenjski pristop (angl. multi-scale), ki lastnosti objektov prepoznava $\mathrm{v}$ več merilih in ustvarja mednivojsko povezljivost (glej Baatz in Schäpe, 2000; Definiens, 2011). Algoritmi segmentacije kombinirajo posamezne piksle v segmente ob upoštevanju treh kriterijev homogenosti: homogenost znotraj segmenta, ločenost (drugačnost) od sosednjih elementov in homogenost oblike. Ker kriteriji homogenosti ne morejo biti v celoti izpolnjeni naenkrat, saj se lahko delno izključujejo med seboj, algoritmi segmentacije lahko poudarjajo samo nekatera od njih (Nussbaum in Menz, 2008).

Pri segmentaciji podob naletimo na dvojno težavo. Prvič, na prekomerno segmentacijo (angl. oversegmentation), ki je posledica prevelikega upoštevanja tonskega kontrasta med nekaterimi sosednjimi segmenti, in drugič, na prešibko segmentacijo (angl. undersegmentation), kadar med sosednjimi segmenti ni upoštevanega dovolj kontrasta in se ti med seboj ne ločijo na več segmentov. Slika 5 prikazuje primere prekomerne, ustrezne in prešibke segmentacije. Prekomerna segmentacija je manjša težava od prešibke, saj je segmente v kasnejših fazah lažje združevati kot jih razdruževati. Dobra segmentacija je vseeno tista, pri kateri ne prevladuje nobena od skrajnosti (Blaschke et al., 2008). 


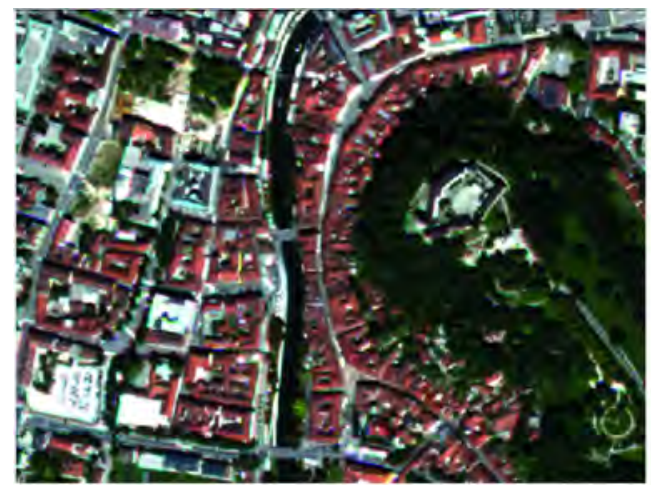

a)

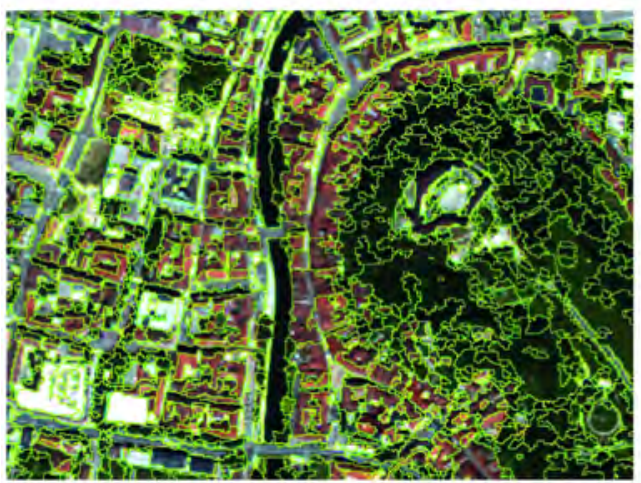

c)

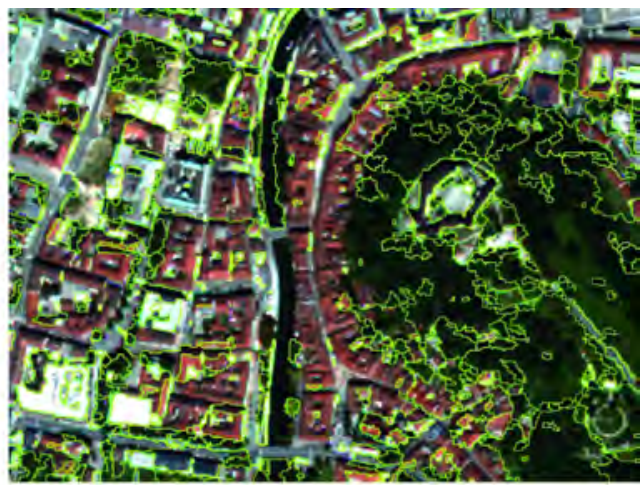

b)

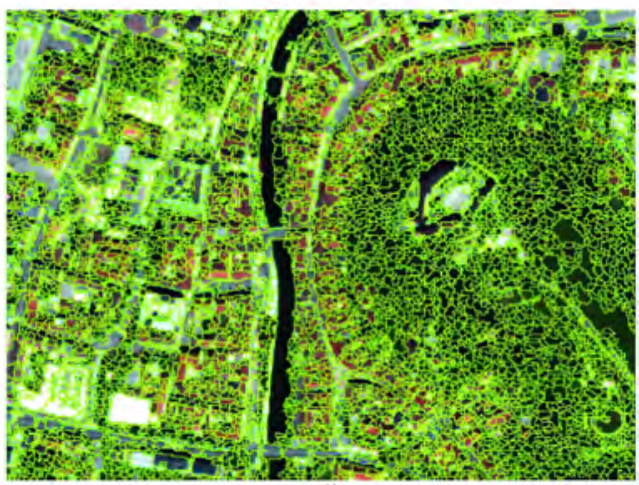

d)

Slika 5: Slika (a) prikazuje območje središča Ljubljane, segmentirano z različnimi stopnjami segmentacije. Primer prešibke (b), ustrezne (c) in prekomerne (d) segmentacije.

Atributi segmentov opisujejo lastnosti posameznega segmenta. Delimo jih na (Navulur, 2007): geometrične (npr. površina, obod, razpotegnjenost, kompaktnost), spektralne (npr. povprečje, standardni odklon, najmanjša in največja vrednost posameznega kanala), teksturne (npr. razpon, entropija, variabilnost), atribute razmerij spektralnih kanalov (npr. vegetacijski indeks), kontekstualne (npr. bližina sosednjih pikslov, oddaljenost), časovne (npr. časovno obdobje, datum, obstojnost) in podobno. Število izračunanih atributov za vsak segment je lahko zelo veliko, velikostnega reda nekaj deset.

\subsubsection{Objektna (semantična) klasifikacija}

Objektna (semantična) klasifikacija razvrsti segmente na podlagi njihovih značilnosti v objektne razrede. $\mathrm{Z}$ izbrano stopnjo zaupanja se primerjajo posamezne značilnosti (atribute) segmenta in določi »pripadnost « (angl. membership) nekemu razredu (Nussbaum in Menz, 2008). Pripadnost segmentov objektom ali objektnim razredom/tipom se lahko določa z različnimi pristopi. Objekte klasificiramo bodisi s hevrističnimi metodami ali s tehnikami, ki temeljijo na znanju, kot so semantične mreže (Blaschke et al., 2008; Nussbaum in Menz, 2008; Navulur, 2007). Semantični sistemi delujejo tako, da vzpostavimo niz pravil za klasifikacijo, s katerimi opišemo, kako naj se objekti na podobi združujejo in razporejajo v razrede. Najbolj običajni tehniki sta: določitev 
učnih vzorcev in opredelitev pravil na podlagi reprezentativnih mejnih vrednosti (po navadi so to odločitvena drevesa), ki jih opredelimo za vsak ciljni objektni tip. Klasifikacijo (izvedbo pravil) opravimo z izbrano metodo ali klasifikatorjem. Med bolj prepoznavne klasifikatorje štejemo (Schowengerdt, 2007; Oštir, 2006; Lillesand et al., 2004):

- parametrični in neparametrični statistični klasifikatorji (npr. K-Means, ISODATA, metoda najmanjše razdalje, metoda največje verjetnosti, metode najbližjih sosedov, paralelepipedna metoda, podpora vektorskih strojev (različice SVM)),

- klasifikatorji na podlagi umetnih nevronskih mrež (s povratno informacijo, metoda Kohonen),

- klasifikatorji na podlagi strojnega učenja (odločitvena, klasifikacijska in regresijska drevesa),

- klasifikatorji, ki temeljijo na uporabi mehke logike (pripadnosti), itn.

Slika 6 prikazuje rezultate uporabe dveh semantičnih sistemov klasifikacije (določitev učnih vzorcev, uporaba odločitvenih dreves) na izseku posnetka Landsat za širše območje Ljubljane. Rezultata sta precej različna, na podlagi vizualnega vrednotenja pravilnih in napačnih razvrstitev razpoznanih objektov $v$ objektne tipe ocenjujemo, da je rezultat $\mathrm{z}$ določitvijo vzorcev pravilnejši. Pri klasifikaciji heterogene geografske stvarnosti (ko hkrati analiziramo več objektov in objektnih tipov) je oblikovanje niza pravil za razvrščanje v tematske razrede težavna naloga. Pogoji se lahko prekrivajo ali izključujejo, kar omejuje točnost končnih izidov klasifikacije. Za klasifikacijo, ki temelji na uporabi odločitvenih dreves, je značilno, da je uspešna pri zaznavi tipičnih (praviloma antropogenih) značilnostih na površju, ki so zgrajene v skladu z določenimi standardi in so zato razmeroma enostavne za opredelitev z nizom pravil (Lang in Blaschke, 2003). Uspešna je tudi pri prepoznavanju jasno razpoznavnih vzorcev na podobi, kot je na primer voda na radarskih posnetkih (Veljanovski et al. 2011a).

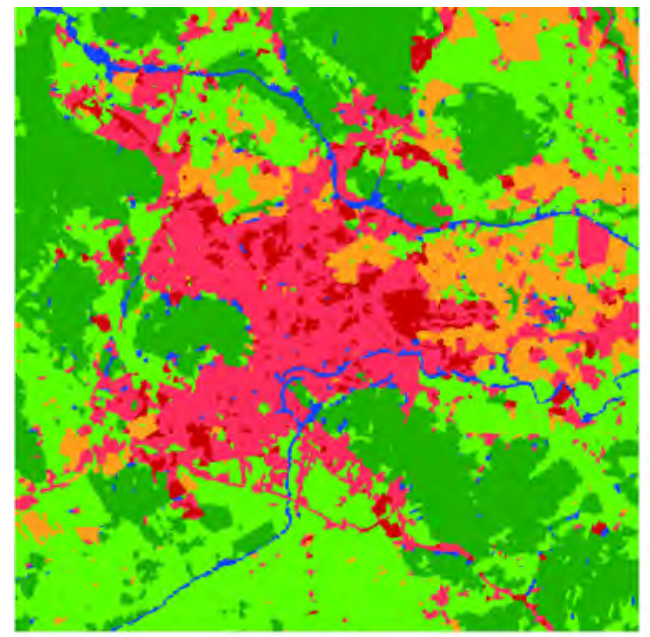

urbane sive $\square$ urbane bele $\square$ dozorele njive $\square$ zelene/travniki $\square$ gozd $\square$ vode a)

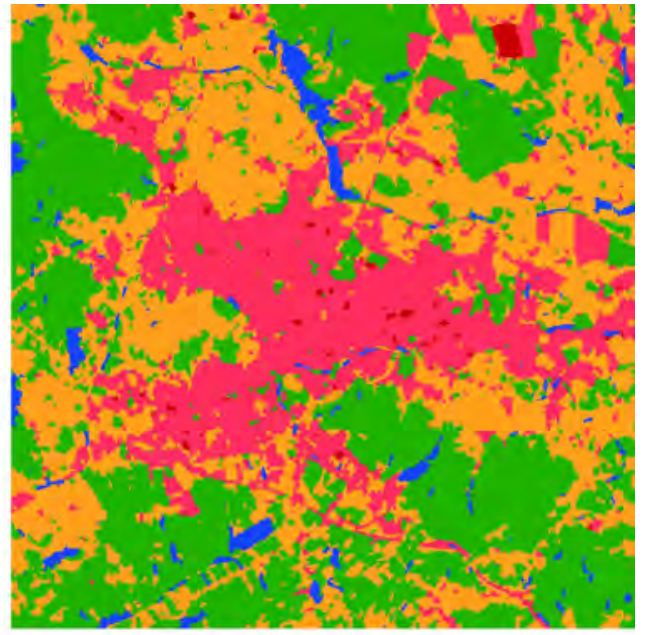

Jurbane sive $\square$ urbane bele $\square$ dozorele njive vode $\square$ gozd

b)

Slika 6: Primer klasifikacije na območju Ljubljane: (a) z uporabo učnih vzorcev (kot klasifikator je uporabljena SVM) in (b) z uporabo pravil (odločitvena drevesa). 
Kakovost končnih opredelitev klasifikacije je neposredno odvisna od kakovosti segmentacije in kakovosti klasifikatorja. Kakšna je dejanska zanesljivost, doslednost in ponovljivost določitve segmentov in razvrstitve $\mathrm{v}$ objekte ter odvisnost od nastavitev modela, je tehtno vprašanje, ki nima enoličnega odgovora. Podrobnejših sistematičnih in primerjalnih študij o izpostavljenih vprašanjih v literaturi nismo zasledili.

\subsubsection{Poklasifikacija}

Namen poklasifikacije je odpraviti očitne napake (razvrstitve objektov v napačne razrede) in rezultate ustrezno posplošiti. Očitne napake odpravimo z vizualno kontrolo, terenskim pregledom ali primerjavo z referenčnim virom, če je ta na razpolago. Postopek je pretežno ročen in zato dolgotrajen.

Generalizacija dobljenih objektnih razredov je smiselna zaradi izboljšanja kakovosti podobe in vsebine končnega produkta - tematske karte. Če na primer ne želimo ohraniti majhnih objektov, jih lahko z operacijama »združi in presej« (angl. clump and sieve) združimo s prevladujočimi razredi v okolici (Kokalj, 2006). Funkciji sta izvedljivi na rastrskih podatkih klasifikacije. Med zaključne postopke priprave končnih tematskih kart v vektorski obliki je smiselno uvrstiti glajenje linij (angl. smoothing). Ta korak je posebej dobrodošel, če objektno klasifikacijo izvajamo na posnetkih srednje ločljivosti, saj rešuje težavo zalomljenosti linij, ki sledijo obliki in razporeditvi pikslov.

\subsubsection{Ocena natančnosti klasifikacije}

Za ovrednotenje rezultatov objektne klasifikacije se uporabljajo skoraj identični postopki kot pri pikselski klasifikaciji, ocenjuje se kakovost razdelitve segmentov v objektne razrede. Za primerjavo uporabljamo referenčno podobo ali druge (časovno, vsebinsko in položajno) ustrezne prostorske vire. Natančnost klasifikacije izraža stopnjo, do katere se podatki, pridobljeni s klasifikacijo, ujemajo z resničnostjo (Campbell, 1996), torej je napaka klasifikacije razlika med tematsko karto in resničnostjo. Matrika napak (angl. confusion matrix) v obliki navzkrižne tabele podaja odnos med referenčnimi podatki in rezultati klasifikacije $\mathrm{v}$ odstotkih pravilno razvrščenih razredov (Congalton in Green, 1999). Klasifikacijo največkrat ocenjujemo na podlagi vzorčnih točk, za katere sta položaj in pomen dobro znana, pri čemer merilo podatkov ne igra vloge. Da ima ocena natančnosti pomen, morajo biti primerjani podatki med seboj vsestransko (prostorsko in časovno) usklajeni. Slabšo ocenjeno natančnost klasifikacije pri primerjavi dveh tematskih virov lahko povzroči tudi različno izvorno merilo, saj so pridobljeni objekti posplošeni na različnih ravneh.

Tovrstne kvantitativne ocene natančnosti se uporabljajo za ocenjevanje verjetnosti pravilnih razvrstitev razredov ter splošno kakovost ali zanesljivost rezultata klasifikacije. Ker pa na kakovost končnih rezultatov objektne klasifikacije vplivajo vsi predhodni koraki in uporabljeni postopki, se vse več pozornosti namenja tudi ločeni oceni kakovosti segmentacije in semantične klasifikacije.

Pregled tehnik za oceno kakovosti segmentacije podob je podal Neubert s sodelavci (2008). Opravili so tudi obsežno študijo učinkovitosti meril za oceno natančnosti, ki jih vsebujejo posamezni programi za objektno usmerjene analize podob. Ugotovili so, da je pridobitev relevantne 
ocene kakovosti segmentacije zahtevna in težka naloga predvsem zaradi raznolikosti delovanja algoritmov in narave segmentacije, ki izhaja iz parametrizacije več odločitvenih dejavnikov. Z oceno kakovosti segmentacije na podlagi indeksov prileganja in odstopanja segmentov sta se ukvarjala Radoux in Defourny (2008). Z indeksom prileganja (normalizirani postsegmentacijski standardni odklon) sta ugotavljala tematsko natančnost segmentov, z indeksom odstopanja (načelo Bhattacharyjeve razdalje znotraj razreda, tako mero standardnega odklona kot sredine velikosti objekta) pa sta vrednotila točnost robov pridobljenih segmentov. Ugotovila sta, da uporabljeni indeks prileganja dobro zaznava razlike med rezultati segmentacije z različno nastavljenimi parametri in omogoča sistematično vrednotenje. Ker pa pri tem niso upoštevane tudi položajne napake vzdolž robov segmentov in niso prepoznani primeri prešibke segmentacije, predlagata komplementarno uporabo obeh indeksov. Z uporabo obeh pravil namreč ne le ocenimo, temveč lahko tudi izboljšamo segementacijo, še posebej če je prešibka.

$\mathrm{Z}$ dolocitvijo tematske nezaneslivivosti po klasifikaciji (angl. thematic uncertainty) sta se ukvarjala Schiewe in Gähler (2008). Razvila sta novo mero, ki upošteva nezanesljivosti referenčnih podatkov in dejstvo, da se večina objektov $\mathrm{v}$ naravi ne zaključuje $\mathrm{z}$ ostrimi robovi. Temelji na kriteriju mehke pripadnosti (angl. fuzzy certainty measure). Predlagana mera modelira in vrednoti nekonsistentnosti med robovi objektov v referenčnih podatkih in v rezultatu objektne klasifikacije.

\subsection{Prednosti in omejitve objektne klasifikacije}

Nova metodologija se razvije bodisi zato, ker skuša preseči pomanjkljivosti obstoječe, ali ker se spremeni paradigma opazovanja problematike in so potrebni novi metodološki prijemi. Preskok s pikselsko usmerjenega na objektno usmerjeni pristop v daljinskem zaznavanju z visokoločljivimi sistemi sodi med slednje. Metodologija za objektno klasifikacijo posnetkov je vzpostavljena, je pa še daleč od popolnosti. Zavedati se je treba, da je objektno usmerjen pristop praviloma naravnan na reševanje specifične težave, zato je temu prilagojena tudi izvedba posamičnih korakov. $Z$ naštetih vidikov vrednotimo lastnosti objektno usmerjenih analiz in trenutnih tehničnih zmožnosti pri implementaciji (Hay et al., 2003; Lang et al., 2006; Navulur, 2007; Blaschke et al., 2008; Nussbaum in Menz, 2008; Kanjir, 2009).

\section{Prednosti objektne klasifikacije:}

- Izkorišča velik spekter lastnosti daljinsko zaznanih podatkov (spektralne, prostorske, časovne) ter jih povezuje s funkcionalnostmi GIS v različnih fazah obdelave: uporaba in upoštevanje dodatnih informacij in slojev, odnosov, kot je npr. oddaljenost, izraženih prek raznih prostorskih funkcij v klasifikaciji, ter za glajenje in posploševanje v generalizaciji rezultatov.

- Uporabljajo se vse razpoložljive, uporabne lastnosti segmentov za njihovo razvrščanje (npr. oblika, tekstura, odnosi z drugimi segmenti).

- Identificirani objekti so vektorji, zahtevajo manj poobdelave kot rezultati pikselske klasifikacije. Določeno generalizacijo izvajamo že v okviru postopka (npr. izločanje majhnih predmetov na podlagi atributov oblike).

- Način ločevanja vsebine posnetkov na objekte je soroden človeški konceptualni shemi razumevanja okolja. Rezultati so že ustrezno generalizirani, saj klasifikacija poteka po 
semantičnih pravilih, prek katerih lahko poudarimo ali zanemarimo določene izrazite lastnosti objektov (npr. linearnost, dolžino, širino, pravokotnost za stavbe), pa tudi ključne medsebojne razlike (npr. tipično velikost pojavljanja v naravi).

- Uporaba objektov kot osnovnih enot zmanjšuje zahtevnost računskih algoritmov in hkrati omogoča, da se izkoristijo računsko bolj zapletene tehnike in širši nabor opisa podatkov za obdelave (vpeljava konceptualnih atributov).

- Število prosto dostopnih programov za objektno usmerjene analize narašča, povezljivost med programi se veča.

- Je interaktiven,večstopenjski proces. Omogoča sprotno opazovanje rezultatov vmesnih korakov in s prenastavljanjem parametrov sprotne izboljšave.

\section{Omejitve objektne klasifikacije:}

- Pri obdelavi obsežnih baz podatkov (velika prostorska pokritost, visoka prostorska ločljivost podatkov ali oboje) je potrebna velika procesorska moč strojne opreme, saj pri segmentaciji multispektralnih podob obravnavamo zelo veliko pikslov naenkrat.

- Segmentacija nima enotne rešitve. Že z majhno spremembo radiometrične ločljivosti podatkov, spremenjeno nastavitvijo parametrov segmentacije ali pri različni predpripravi posnetkov dobimo drugačne rezultate.

- Objektni način klasifikacije je nova metoda daljinskega zaznavanja, zato na tem področju še ni dovolj soglasij in raziskav pri odnosu med objektom, ustvarjenim pri postopku segmentacije in klasifikacije, in geografskim objektom. Podobno tudi postopki za vrednotenje kakovosti izvedbe posameznih korakov niso niti številčni niti toliko razviti, da bi bili vpeti v programsko opremo.

- Razumevanje stopenj in hierarhičnih odnosov med objekti, pridobljenimi pri različnih prostorskih ločljivostih, je razmeroma slabo raziskano. Postopki, ki omogočajo objektne analize $\mathrm{v}$ več merilih, nimajo zadostne zaslombe povezljivosti in sledenja objektov v praktičnih implementacijah.

- Zaradi kompleksne geografske stvarnosti in raznolikosti lastnosti satelitskih posnetkov, ki jo na različne načine upodabljajo, postopki niso bili zasnovani, da bi bili popolnoma samodejni, temveč da bi zadostili čim širšemu spektru aplikacij. Samodejnost ostaja izključno v domeni ozko specificiranih nalog obravnave izbranih objektov.

- Šibka točka je tudi doslednost določanja objektov z vidika razpoznavanja/ohranjanja osnovnih geometričnih prvin objektov ter ponovljivosti postopka razpoznave v spremenjenih naravnih ali tehnoloških okoliščinah.

Uporaba objektno usmerjenega pristopa ima smisel, če zagotavlja prednosti v primerjavi z ostalimi metodami. Opravljenih je bilo kar nekaj študij o primerjavi pikselske in objektne klasifikacije. Primerjave obeh klasifikacij kažejo, da je na posnetkih s srednjo (kot so Landsat TM/ETM+ in SPOT-5) in visoko prostorsko ločljivostjo (Ikonos, QuickBird, WorldView) mogoče z objektno usmerjeno metodo pridobiti boljše rezultate (Baatz in Schäpe, 2000; Willhauck et al., 2000; Hay et al., 2005; Kamagata et al., 2005; Manakos et al., 2000; Whiteside in Ahmad, 2005; Yan et al. 
2006). Številne praktične aplikacije dokazujejo tudi, da je določene pojave (pojavljanje izbranih geografskih objektov) mogoče hitreje in bolj zanesljivo prepoznavati z objektnim pristopom kot pikselskim. Nasprotno pa so študije pokazale, da na podobah z nizko ločljivostjo (od 100 do $250 \mathrm{~m}$ ) objektna klasifikacija ni dosegla boljših rezultatov od pikselske.

\section{ORIS APLIKACIJ OBJEKTNO USMERJENIH ANALIZ V DALJINSKEM ZAZNAVANJU}

$\mathrm{V}$ tiskanih in spletnih publikacijah je veliko primerov uporabe objektno usmerjenih pristopov na satelitskih posnetkih, ki odražajo tudi opravljene raziskave na področju. Pomemben pregled študij ponujata spletni portal Definiens (2011) in portal Centra za geomatiko na salzburški univerzi Z_GIS (2011). Blaschke (2010) navaja, da se je število prispevkov na temo objektno usmerjenega pristopa začelo povečevati leta 2000 in še zelo narašča.

Tu povzemamo glavne smeri bolj prelomnih aplikacij z objektno usmerjenim pristopom: razčlenjevanje in opazovanje večjih površin zemeljskega površja (Blaschke, 2005; Chandra et al., 2005; Crase in Hempel, 2005; Laliberte et al., 2005; Whiteside, 2005), opazovanje urbanih območij in njihovega širjenja (Chunyang et al, 2005; Grenzdoerfer, 2005; Moeller, 2005), pridobivanje informacij ob nesrečah (Bitelli et al., 2004; Heremans et al., 2005; Kouchi in Yamazaki, 2005), opazovanje površin jedrskih objektov (Niemeyer in Canty, 2001; Nussbaum in Menz, 2008), identifikacija vegetacije (Peña-Barragán et al., 2011), opazovanje habitatov in biotopov, natančno razčlenjevanje in prepoznavanje vegetacije ter kmetijskih površin. Zainteresiran bralec lahko dobi podrobnejši vpogled v izčrpnem pregledu Blaschkeja (2010).

Večina aplikacij je za izvedbo uporabila program eCognition, del tudi ENVI, del pa lastne rešitve. Glavna kritika obstoječih programov se nanaša na težave, ki izhajajo iz prešibke in prekomerne segmentacije objektov, ter na pomanjkljivost orodij za oceno kakovosti posameznih korakov. Algoritmi za izboljšano segmentacijo in nadgradnjo analize objektov so tako še v intenzivni fazi razvoja (Blaschke et al., 2008; Nussbaum in Menz, 2008; Navulur, 2007), s tem pa tudi nove možnosti izvedbe in aplikacij.

\subsection{Uporaba objektno usmerjenih analiz satelitskih posnetkov v Sloveniji}

V Sloveniji lahko med zametke objektno usmerjenega pristopa uvrstimo študije, ki se navezujejo na izdelavo in analize tematskih kart (klasifikacijo) rabe/pokrovnosti tal (Šabić et al., 2000; Kokalj in Oštir, 2006; 2007). Celovitejši primer objektno usmerjenega pristopa ter analize satelitskih in zračnih posnetkov zasledimo pri raziskavah za potrebe gozdarstva in gospodarjenja z gozdovi (Kobler et al., 2006). Objektno usmerjene analize posnetkov so bile uspešno implementirane $\mathrm{v}$ določanje pokrovnosti/rabe tal podalpskega in kmetijskega sveta (Kanjir et al., 2010), širitve urbanih površin Ljubljane (slika 7; Kanjir et al., 2011a) ter v določanje poplavljenih površin ob poplavah septembra 2010 iz radarskih in optičnih satelitskih in zračnih posnetkov (Veljanovski et al., 2011a, 2011b). Objektni pristop sta za iskanje stavb na satelitskih posnetkih uporabila Grigillo in Kosmatin Fras (2011). Nekatere prvine objektnega pristopa so bile uporabljene tudi pri določitvi stavb za potrebe vzdrževanja topografskih baz (Grigillo et al., 2011). Večstopenjski objektni pristop je bil uporabljen za določanje nepropustnih površin v urbanih okoljih (Kanjir 
et al., 2011b). Naprednejše objektno usmerjene analize pa so bile uporabljene tudi za kartiranje drevesnih vrst $\mathrm{v}$ urbanem okolju in za prepoznavanje invazivnih rastlinskih vrst na obronkih Ljubljane (Đurić, v tisku).

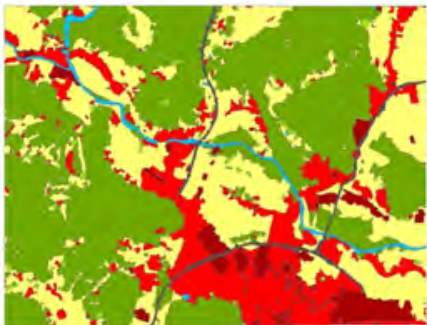

Stanje 1992

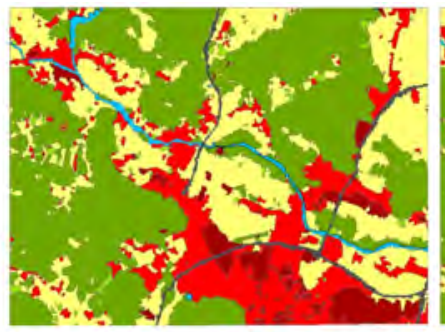

Stanje 1999

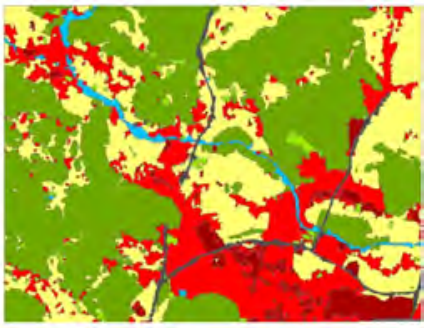

Stanje 2005
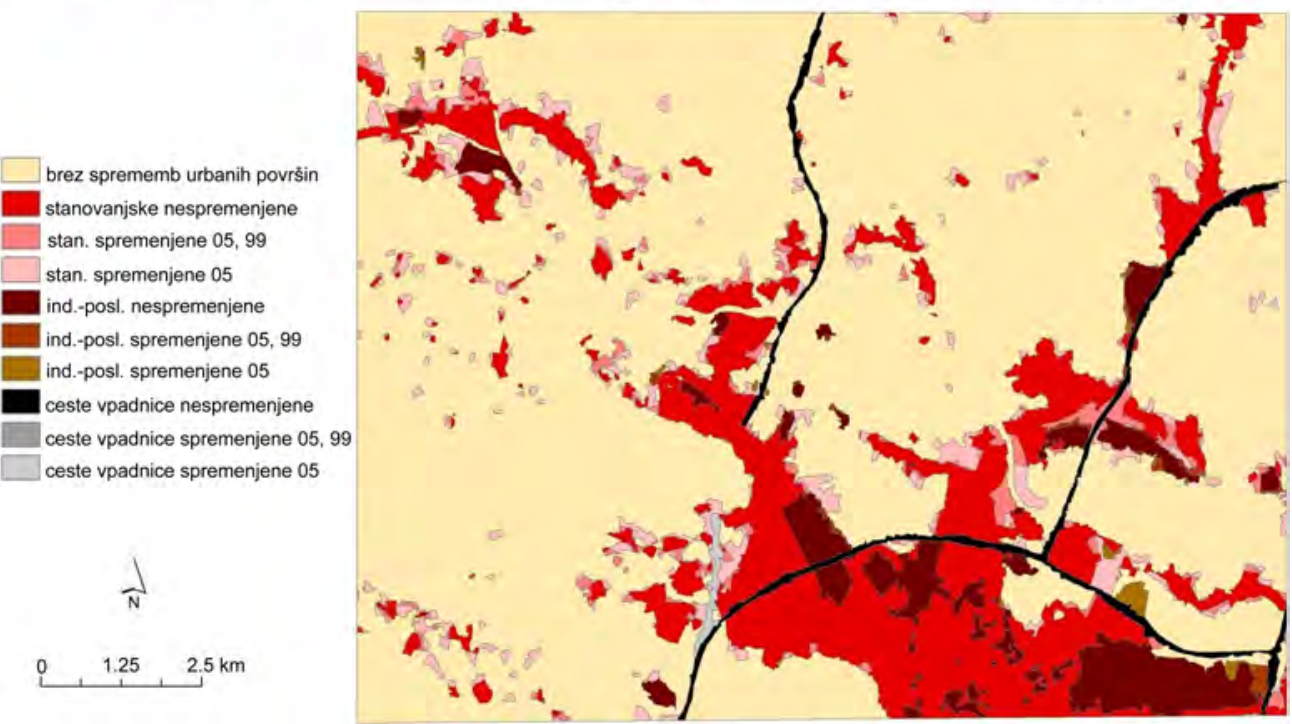

$0 \quad 1.25,2.5 \mathrm{~km}$

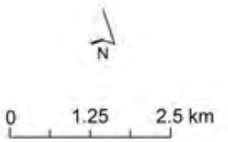

Slika 7: Analiza sprememb urbanih površin z objektno klasifikacijo na izseku Ljubljane z okolico. Zgoraj: rezultati objektne klasifikacije z uporabo učnih vzorcev posnetkov Landsat za leta 1992, 1999 in 2005. $\checkmark$ rdečih tonih so prikazane različne urbane površine. Spodaj: karta analize sprememb širjenja urbanih površin med obravnavanimi časovnimi preseki. Svetlejši barvni odtenki ponazarjajo širitev (rdeči toni stavbne površine, rjavi industrijske in sivi cestne površine).

\section{RAZPRAVA}

Objektno usmerjen pristop je praviloma naravnan na reševanje posamezne aplikacije (npr. razpoznavanje in opazovanje gozdnih sestojev, sprememb urbanih površin), zato je tudi izvedba postopkov največkrat prilagojena specifičnemu namenu. Za kakovostne in uporabne rezultate je zlasti pomembno vsestransko razumevanje delovanja posamičnih korakov v postopku, ki sestavljajo objektno usmerjene aplikacije.

Segmentacija satelitskih podob je ključna, nikakor trivialna naloga, ki prinaša tri nerešene izzive. V časovnih študijah se srečujemo s težavo doslednosti in ponovljivosti segmentacije na časovno zaporednih posnetkih z uporabo enotno nastavljenih parametrov. Pri primerjavi 
podatkov različnih prostorskih ločljivosti je problematična primerljivost razpoznave objektov (različna merila opazovanja, omejenost z natančnostjo meritve). Najbolj splošna težava pa je, kako obravnavati spektralno in prostorsko variabilnost objektov istega ali različnih objektnih tipov ter stopnje podrobnosti, ki jo pri nekaterih objektih želimo ohraniti (npr. obris stavbe, posamično drevo v naselju), pri drugih pa ne (npr. prevelika razdrobljenost v večjih gozdnih površinah). Potencial na tem področju ima večločljiva ali večnivojska objektna analiza, ki pomeni analizo vsebine posnetka v različnih merilih. Rezultati so obetavni, težave v praksi pa še povzročata hierarhična povezljivost komponent in prenos informacij, pridobljenih v novonastalem hierarhičnem sistemu (segmenti in njihove lastnosti na različnih ravneh merila), v nadaljnje korake obdelave (Hay et al., 2003).

Objektno usmerjena programska podpora je trenutno dobra rešitev za posamične, specifično naravnane naloge, recimo enkratno klasifikacijo površja. Slabše pa podpira večkratne analize na objektih. Ko se bosta izboljšali tudi dostopnost in zmogljivost objektnega pristopa v več merilih, bo objektno usmerjena analiza posnetkov nedvomno pripomogla h koherentnejšemu razumevanju geografskih objektov v okolju in njihovi reprezentaciji na daljinsko zaznanih podobah, ne glede na vir vhodnih podatkov in uporabljeno opremo.

\subsection{Sedanje omejitve v objektno usmerjenih analizah}

Trenutne omejitve v objektno usmerjenih analizah daljinsko zaznanih podatkov lahko ločimo na tiste, ki se nanašajo na teoretična izhodišča, in tiste, ki se nanašajo na uresničitev objektne analize ali izvedbo v praksi.

Za razumevanje struktur v okolju (tj. geografskih objektov), njihove reprezentacije na daljinsko zaznanih podobah in rezultatov, ki jih pridobimo z objektnim načinom klasifikacije, še ni skupnega soglasja, ali dosegamo želeni cilj objektno usmerjenega pristopa. Raziskav odnosov med objektom, ustvarjenim v postopku segmentacije in klasifikacije, in realnim geografskim objektom - tj. vrednotenja, kako določeni objekti ustrezajo vsebini in oblikam, ki jih zavzemajo dejanski objekti v naravi - je malo. Zato ne poznamo šibkih točk, pri katerih se najpogosteje pojavljajo napake pri določitvi izhodiščnih segmentov na podobi, in načina prenosa napak $\mathrm{v}$ semantičnem modeliranju (Hay in Castilla, 2006). V prihodnosti lahko pričakujemo predvsem razvoj za oblikovanje večnivojske reprezentacije objektov ter podpore razpoznavanju in sledenju objektov v več merilih. Temu bo sledil razvoj novih meril za oceno kakovosti in ustreznosti objektno usmerjenih analiz.

Geografska stvarnost je heterogena in v odnosih zapletena struktura. Objektno usmerjena analiza satelitskih posnetkov površja ponuja širok nabor atributov za semantično modeliranje. Vsak uporabnik pri reševanju naloge išče in kombinira mnoštvo tovrstnih, a za nalogo koristnih informacij. Praviloma je treba za vsako nalogo sistem najboljšega prepoznavanja objektov vzpostaviti na novo. Tu bi bila banka optimalnih kombinacij atributov vsaj za reprezentativne objekte več kot dobrodošla. Sistematičnih raziskav na to temo nismo zasledili.

Objektno usmerjen pristop sestavlja več korakov, ki so po naravi bolj ali manj parametrični postopki (temeljijo na trenutnem izboru parametrov). Tako lahko pravila razvrščanja optimalno 
prilagodimo dani situaciji, to je lastnostim podatkov in namenu analize. Ob tem velja opozoriti, da parametrično zasnovani postopki ne podpirajo neposredne (popolne) prenosljivosti in ponovljivosti postopka na druge naloge ali druge podatke, ali pa jih podpirajo le v omejenem obsegu (npr. ohranimo oblikovan niz pravil, spremenimo argumente mejnih vrednosti). Prenosljivost ustvarjenega odločitvenega drevesa je vselej omejena, saj je odvisna od vseh lastnosti posnetka, na katerem je bilo drevo odločitev razvito.

Omejitve trenutnega stanja objektno naravnanih tehnologij so še najbolj razvidne v časovnih študijah ali analizi sprememb, pri katerih na časovno zaporednih posnetkih stremimo k opredelitvi optimalne kombinacije parametrov, ki bi zagotovila ponovljivost postopka in primerljivost rezultatov objektne klasifikacije. Trenutno največ težav povzroča nedoslednost pri razpoznavi istih geografskih objektov na različnih posnetkih. Segmentacija na sicer podobnih posnetkih (npr. isti senzor, ločljivost) nima enotne rešitve. Tu se kot boljša možnost znova ponuja segmentacija, ki prepoznava vlogo in značilno reprezentacijo objektov v različnih merilih, ali privzem geometrije objektov iz drugih slojev, referenčnih podatkov, a z nadaljnjo objektno obdelavo. Objektno usmerjene časovne primerjave resda učinkovito premoščajo nekatere ključne omejitve pikselskega pristopa (Veljanovski, 2008): vzorcu sprememb dajo tematski pomen, s čimer znatno olajšajo interpretacijo vzorca sprememb, uspešnost ni pogojena z radiometrično konsistentnostjo časovne vrste posnetkov itn. Vendar je sledljivost objektov $\mathrm{v}$ objektno usmerjeni analizi sprememb tehnično in vsebinsko izjemno zahtevna naloga, saj je treba upoštevati tako nestabilnost oziroma spremenljivost oblik objektov razpoznanih na različnih, časovno zaporednih posnetkih kot tudi njihove dejanske semantične manifestacije v času. Sledenje objektov in tehnološki odgovor na analize njihovega udejanjanja $\mathrm{v}$ času je v obstoječih programih za objektno usmerjene analize daljinsko zaznanih podatkov še nerešena naloga in je tako rekoč brez programske podpore.

V zvezi s povezovanjem zmožnosti obstoječe programske podpore in potenciala, ki ga ponuja objektno usmerjena paradigma za analize, ugotavljamo tudi, da so možnosti analize spektralnega prostora v objektu še povsem neizkoriščene. V prihodnosti gotovo lahko pričakujemo širjenje nabora računanih atributov v naslednjih smereh: spektralni podpis objekta, opisi geometrične (pod)strukture objekta in podobno. Z upoštevanjem in ustrezno obravnavo tovrstnih, kompleksnejših atributov bo tudi prepoznavanje in razlikovanje med objekti s sorodnimi lastnostmi (npr. zorane njive - tlakovane površine) mnogo boljše.

\section{SKLEP}

Napredek na področju optičnih, radarskih in laserskih metod zajema podatkov ustvarja vedno bolj podrobne (vedno bolje ločljive) podatkovne vire. Ti po eni strani izboljšujejo možnosti interpretacije, hkrati pa močno otežujejo samo obdelavo. Pri satelitskih posnetkih visoke ločljivosti ta zahteva postopke, ki so podobni vizualni interpretaciji in ne temeljijo na posameznem pikslu, temveč na skupinah pikslov - objektih - in relacijah med njimi. Objektno usmerjena analiza satelitskih podatkov ponuja boljšo in človekovemu dojemanju bližjo interpretacijo od pikselske. Tako pripomore $\mathrm{h}$ koherentnejšemu razumevanju geografskih objektov v okolju in njihovi reprezentaciji na daljinsko zaznanih podobah. 
Čeprav se je objektno usmerjena analiza podob razširila in uveljavila šele pred dobrim desetletjem, temelji na postopkih (segmentacija, zaznavanje robov, klasifikacija), ki so v daljinskem zaznavanju uveljavljeni že desetletja. Velik napredek je povzročil razvoj programske opreme, saj je ta v relativno kratkem času iz nišnega, raziskovalnega okolja prišla v zelo kakovostne samostojne izdelke (eCognition je še vedno sinonim za objektno usmerjeno analizo) in v vse večje programe za obdelavo satelitskih posnetkov (večinoma kot dodatni modul, npr. ERDAS Objective, ENVI Feature Extraction).

Na področju objektne analize podatkov daljinskega zaznavanja potekajo izredno živahne raziskave in razvoj. Čeprav številna vprašanja, recimo segmentacija ali opazovanje sprememb in vrednotenje rezultatov, še niso zadovoljivo rešena, lahko spremljamo uporabo na številnih področjih. Objektno usmerjena analiza podatkov daljinskega zaznavanja je postala ključni dejavnik večnivojske analize površja in je kot taka pomembna povezava med daljinskim zaznavanjem ter geografskimi informacijskimi sistemi. Zmanjšuje namreč razkorak med informacijami GIS, parametri, zajetimi z različnimi senzorji, in strokovnim znanjem. Tako omogoča neslutene možnosti (samodejne) analize objektov.

\section{Zahvala}

Javna agencija za raziskovalno dejavnost Republike Slovenije je financirala podoktorski raziskovalni projekt (Z2-2127). Center odličnosti Vesolje, znanost in tehnologije je operacija, ki jo delno financirata Evropska unija, Evropski sklad za regionalni razvoj ter Ministrstvo za visoko šolstvo, znanost in tehnologijo Republike Slovenije. Hvala Petru Pehaniju in recenzentoma dr. Mojci Kosmatin Fras in dr. Dejanu Grigillu za temeljit pregled in predloge, kako izboljšati in urediti prispevek.

\section{Literatura in viri:}

Addink, E.A., Van Coillie, F.M.B. (eds.) (2010). GEOBIA2010: Geographic object-based image analysis, Ghent, Belgium, 29. June - 2. July 2010. ISPRS Vol. No. XXXVIII-4/C7, Archives ISSN No 1682-1777. http://geobia.ugent.be/proceedings/ html/papers.html (April 2011).

Albertz, J. (2001). Einführung in die Fernerkundung.Grundlagen der Interpretation von Luft- und Satellitenbildern. WissenschaftlicheBuchgesellschat, Darmstalt.

Baatz, M., Schäpe, A. (2000). Multi-resolution segmentation - an optimization approach for high quality multi-scale segmentation. In: Strobl, J., et al. (eds.), Angewandte Geographische Informations verarbeitung XII, Beiträgezum AGIT Symposium Salsburg 2000, Karlruhe, Herbert Wichmann Verlag, 12-23.

Beaudoin, A., Le Toan, T., Lopes, A., Laur, H. (1990). Forest and land use segmentation of SAR images using backscatter and textural information. In:10th Annual International Geoscience and Remote Sensing Symposium, College Park, MD, IEEE 90 CH2825-50, IEEE, Piscataway, NJ, 871-874.

Bitelli, G., Camassi, R., Gusella, R., Mongol, A. (2004). Image change detection on urban area: The earthquake case. In: Proceedings of the ISPRS2004 annual conference, Istanbul, Turkey, 19.-23. July 2004.

Blaschke, T. (2005). A framework for change detection based on image object. In: Erasmi, S., Cyffka, B., Kappas, M. (eds.) Göttinger Geographische Abhandlungen 113, 1-9.

Blaschke, T. (2010). Object based image analysis for remote sensing. ISPRS Journal of Photogrammetry and Remote Sensing, 65, 2-16.

Blaschke, T., Lang, S., Hay G.J. (eds.) (2008). Object-Based Image Analysis: Spatial Concepts for Knowledge-Driven Remote Sensing Applications (Lecture notes in geo-information and cartography). Springer. 
Blaschke, T., Strobl, J. (2001). What's wrong with pixels? Some recent developments interfacing remote sensing and GIS.GIS-Zeitschrift für Geoinformations systeme 14 (6), 12-17.

Campbell, J.B. (1996). Introduction to remote sensing. 2. edition. New York, Guilford Press.

Castilla, G., Hay, G.J. (2008). Geographic object-based image analysis (GEOBIA). In: Blaschke, T., Lang, S., Hay, G.J. (eds.), Object-based image analysis - spatial concepts for knowledge-driven remote sensing applications. SpringerVerlag, Berlin, 91-111.

Chandra, M., Moreira, A., Keydel, W. (2005). Amper: Network on applied multi-parameter environmental remote sensing. An EU sponsored research and training network. In: Proceedings of the IGARSS 2005 Symposium. Seul, Korea. 25.-29. July 2005.

Chunyang, H., Li, J., Zhang, J., Pan, Y., Chen, Y.H. (2005). Dynamic monitor on urban expansion based on an objectoriented approach. In: Proceedings of the IGARSS 2005 Symposium. Seul, Korea. 25.-29. July 2005.

Congalton, R.G., Green, K. (1999). Assessing the accuracy of remotely sensed data: principles and practices. Lewis Publisher.

Cracknell, A.P. (1998). Synergy in remote sensing - What's in a pixel? International Journal of Remote Sensing 19 (11), 2025-2047.

Crase, B., Hempel, C. (2005). Object based land cover mapping for groote eylandt: a tool for reconnaissance and land based surveys. In: Proceedings of NARGIS 2005 - Applications in Tropical Spatial Science. Charles Darwin University, Darwin, NT, Australia. 4.-7. July 2005.

Definiens (2011). Definiens Solutions. http://www.definiens.com/, http://community.definiens.com/home.html, http:// www.ecognition.com/learn/resource-center/show-more?type=Scientific\%20Paper (April 2011).

Đurić, N. (in press). Object-based classification for extracting tree species and detection of japanese knotweed. Graduation thesis. Ljubljana: Faculty of Civil and Geodetic Engineering, Department of Geodetic Engineering.

ENVI (2004). ENVI User's guide.http://aviris.gl.fcen.uba.ar/Curso_SR/biblio_sr/ENVI_userguid.pdf(April 2011).

Gao, Y., Kerle, N., Mas, J. F., Navarrete, A., Niemeyer, I. (2007). Optimized image segmentation and its effect on classification accuracy. Poster session on 5th international Symposium on Spatial Data Quality, Enschede, The Netherlands.

GEOBIA Wiki (2011). GEO Object Based Image Analysis Wikipedia. University of Calgary. http://wiki.ucalgary.ca/ page/GEOBIA (April 2011).

Gonzales, R.C, Woods, R.E. (2002). Digital image processing, 2nd edition. Prentice Hall, Inc.

Grenzdoerfer, G. (2005). Land use change in Rostock, Germany since the reunification - a combined approach with satellite data and high resolution aerial images. In: Proceedings of the ISPRSWG VII/1 Human Settlements and Impact Analysis, 3rd International Symposium Remote Sensing and Data Fusion Over Urban Areas (URBAN 2005) and 5th International Symposium Remote Sensing of Urban Areas (URS 2005). Tempe, AZ, USA. 14.-16. March 2005.

Grigillo, D., Kosmatin Fras, M. (2011). Classification based building detection from GeoEye-1 images. In: Stilla, U. (ed.), JURSE 2011: Proceedings of IEEE-GRSS/ISPRS Joint Urban Remote Sensing Event, TUM, Munich, Germany, 11.-13. April 2011, 381-384. http://ieeexplore.ieee.org/stamp/stamp.jsp?arnumber=05764799 (April 2011).

Grigillo, D., Kosmatin Fras, M., Petrovič, D. (2011). Automatic extraction and building change detection from digital surface model and multispectral orthophoto. Geodetski vestnik 55-1, 28-45.

GTS (2005). Geografski terminološki slovar. Ljubljana: Založba ZRC, ZRC SAZU.

Hall, F.G., Townshend, J.R., Engman, E.T. (1995). Status of remote sensing algorithms for estimation of land surface state parameters. Remote Sensing of Environment. 51, 138-156.

Haralick, R.M., Shapiro, L. (1985). Survey: image segmentation techniques. Comput. Vis. Graph. Image Process. 1985, 29, 100-132.

Hay, G.J., Blaschke, T., Marceau, D.J., Bouchard, A. (2003). A comparison of three image-object methods for the multiscale analysis of landscape structure. ISPRS Journal of Photogrammetry \& Remote Sensing, 57, 327-345.

Hay, G.J., Castilla, G. (2006). Object-based image analysis: strengths, weaknesses, opportunities and threats (SWOT). In: International Archives of Photogrammetry, Remote Sensing and Spatial Information Sciences, Vol. No. XXXVI-4/ C42, Salzburg.

Hay, G.J.,Castilla, G., Wulder, M.A. Ruiz, J.R. (2005). An automated object-based approach for the multi-scale image 
segmentation of forest scenes. International Journal of Applied Earth Observation and Geoinformation, 7, 339-359.

Heremans, R., Willekens, A., Borghys, D., Verbeeck, B., Valckenborgh, J. Perneel, C. (2005). Automatic detection of flooded areas on ENVISAT/ASAR images using an object-oriented classification technique and an active contour algorithm. Proceedings of the 31th International Symposium on Remote Sensing of the Environment. St. Petersburg, Russia. 20.-24. June 2005.

Horowitz, H.M., Lewis, J.T., Pentland, A.P. (1975). Estimating proportions of objects from multispectral scanner data, Final Report, NAS9 Contract NAS9-14123, NASA CR 141826.

Johansen, K., Tiede, D., Blaschke, T., Arroyo, L.A., Phinn, S. (2011). Automatic geographic object based mapping of streambed and riparian zone extent from LiDAR data in a temperate rural urban environment, Australia. Remote Sens. 2011, 3, 1139-1156.

Kamagata, N., Akamatsu, Y., Mori, M., Qing Li, Y., Hoshinoy, Y., Hara, K. (2005). Comparison of pixel-based and object-based classifications of high resolution satellite data in urban fringe areas. In: Proceedings of the 26th Asian Conference on Remote Sensing. Hanoi, Vietnam. 7.-11. November 2005.

Kanjir, U. (2009). Object oriented land use classification from remote sensing data. Graduation thesis. Ljubljana: Faculty of Civil and Geodetic Engineering, Department of Geodetic Engineering.

Kanjir, U., Veljanovski, T., Marsetič, A., Oštir, K. (2010). Application of object based approach to heterogeneous land cover/use. In: Addink, E.A., Van Coillie, F.M.B. (eds.) GEOBIA 2010: Geographic Object-Based Image Analysis, Ghent, Belgium, 29.6.-2.7. 2010. http://geobia.ugent.be/proceedings/html/papers.html (April 2011).

Kanjir, U., Veljanovski, T., Oštir, K. (2011a). Change detection of urban areas - the Ljubljana, Slovenia case study. In: JURSE 2011: Proceedings of IEEE-GRSS/ISPRS Joint Urban Remote Sensing Event, TUM, Munich, Germany. 11.-13. April 2011.

Kanjir, U., Veljanovski, T., Oštir, K. (2011b). Multi level segmentation of soil sealing in urban areas. The 32nd Asian Conference on Remote Sensing, Taipei, Taiwan, 3.-7.10.2011.

Ketting, R.L., Landgrebe, D.A. (1976). Classification of spectral image data by extraction and classification of homogeneous objects, IEEE Transactions Geosci. Electronics 14, 19-25.

Kobler, A., Džeroski, S., Kermatisoglou, I. (2006). Habitat mapping using machine learning-extended kernel-based reclassification of an Ikonos satellite image. Ecol. model., 2006, Vol. 191, No. 1, 83-95.

Kokalj, Ž.,Oštir, K. (2006). Ugotavljanje pokrovnosti Slovenije iz satelitskih posnetkov Landsat. Geografski vestnik, 2006, Vol. 78, No. 2.

Kokalj, Ž.,Oštir, K. (2007). Land cover mapping using Landsat satellite image classification in the classical Karst - Kras region. Acta carsologica 36-3, 433-440.

Kouchi, K., Yamazaki, F. (2005). Damage detection based on object-based segmentation and classification from highresolution satellite images for the 2003 Boumerdes, Algeria earthquake. In: Proceedings of the 26th Asian Conference on Remote Sensing. Hanoi, Vietnam. 7.-11. November 2005.

Laliberte, A., Rango, A., Fredrickson, E. (2005). Classification of arid rangelands using an object-oriented and multiscale approach with QuickBird imagery. In: Proceedings of the ASPRS 2005 Annual Conference. Baltimore, MD, USA. 7.-11. March 2005.

Lang, S., Blaschke, T. (2003). Hierarchical object representation - comparative multi-scale mapping of anthropogenic and natural features. ISPRS Archives 34, Part 3/W8: 17-19.

Lang, S., Blaschke, T., Schöpfer, E. (2006). 1st International Conference on Object-based Image Analysis. http://www. isprs.org/proceedings/XXXVI/4-C42/papers.htm (April 2011).

Liang, S. (2004). Quantitative remote sensing of landsurfaces. New York: Willey-Interscience.

Lillesand, T.M., Kiefer, R.W., Chipman, J.W. (2004). Remote sensing and image interpretation. 5th edition.New York, John Wiley and Sons, Inc.

Manakos, I., Schneider, T., Ammer, U. (2000). A comparison between the ISODATA and the eCognition classification methods on basis of field data. In: ISPRS, Vol. XXXIII, Amsterdam, 2000.

Mason, D.C., Corr, D.G., Cross, A., Hogg, D.C., Lawrence, M., Petrou, D.H., Tailor, A.M. (1988). The use of digital map data in the segmentation and classification of remotely sensed images, Int. J. Geographic Inf. Systems 2, 195-215.

Moeller, M. (2005). Remote sensing for the monitoring of urban growth patterns. In: Proceedings of the ISPRSWG 
VII/1 Human Settlements and Impact Analysis, 3rd International Symposium Remote Sensing and Data Fusion Over Urban Areas (URBAN 2005) and 5th International Symposium Remote Sensing of Urban Areas (URS 2005). Tempe, AZ, USA. 14.-16. March 2005.

Navulur, K. (2007). Multi-spectral image analysis using the object oriented paradigm. CRC Press, Taylor \& Francis Group.

Neubert, M, Herold, H., Meinel, G. (2008). Assessing image segmentation quality - concepts, methods and application. In: Blaschke, T., Lang, S., Hay G.J (Eds.): Object-Based Image Analysis: Spatial Concepts for KnowledgeDriven Remote Sensing Applications (Lecture notes in geoinformation and cartography): 785-803.

Niemeyer, I., Canty, M.J. (2001). Knowledge-based interpretation of satellite data by object-based and multi-scale image analysis in the context of nuclear verification. http:/www.geomonitoring.tu-freiberg.de/publications/ igarss01 nie.pdf (April 2011).

Nussbaum, S., Menz, G. (2008). Object-based image analysis and treaty verification: new approaches in remote sensing - applied to nuclear facilities in Iran. Springer.

Oštir, K. (2006). Daljinsko zaznavanje (Remote Sensing). Ljubljana: Založba ZRC.

Pal, R., Pal, K. (1993). A review on image segmentation techniques. Pattern Recogn. 1993, 26, 1277-1294.

Pena-Barragán, J.M., Ngugi, M.K., Plant, R.E., Six, J. (2011). Object-based crop identification using multiple vegetation indices, textural features and crop phenology. Remote Sensing of Environment, 155-6: 1301-1316.

Quegan, S., Caves, R.G., Grover, K.D., White, R.G. (1992). Segmentation and change detection in ERS-1 images over East Anglia, In: First ERS-1 Symposium: Early Results, ESA, Cannes, France, 617-622.

Radoux, J., Defourny, P. (2008). Quality assessment of segmentation results devoted to object-based classification. In: Blaschke, T., Lang, S., Hay G.J. (eds.): Object-Based Image Analysis: Spatial Concepts for Knowledge-Driven Remote Sensing Applications (Lecture notes in geoinformation and cartography): 257-273.

Richards, J.A., Jia, X. (1999). Remote sensing digital image analysis. An introduction. Springer Verlag, NY.

Schiewe, J. (2002). Segmentation of high-resolution remotely sensed data: concepts, applications and problems. In: Joint ISPRS Commission IV Symposium: Geospatial Theory, Processing and Applications. 9.-12. July 2002. Schiewe, J., Gähler, M. (2008). Modelling uncertainty in high resolution remotely sensed scenes using a fuzzy logic approach. In: Blaschke, T., Lang, S., Hay G.J (Eds.): Object-Based Image Analysis: Spatial Concepts for Knowledge-Driven Remote Sensing Applications (Lecture notes in geoinformation and cartography), 769-785.

Schiewe, J., Tufte, L., Ehlers, M. (2001). Potential and problems of multi-scale segmentation methods in remote sensing. Geographische Informations systeme 6, 34-39.

Schowengerdt, R.A. (2007). Remote sensing. Models and methods for image processing. 3rd edition. Academic Press, Elsevier Inc.

Šabić, D., Lojović, E.H., Tretjak, A. (2000).Ocenjena sprememba pokrovnosti tal v statističnem GISu pokrovnosti in rabe tal Slovenije: junij 1993 - junij 1997. In: Hladnik, D. et al., GIS v Sloveniji 1999-2000, Ljubljana 2000, Založba ZRC, 201-207.

Šumrada, R. (2005). Strukture podatkov in prostorske analize. Ljubljana, Faculty of Civil and Geodetic Engineering.

Veljanovski, T. (2008). The problem of false (non-intrinsic) changes in pixel-based change detection on Landsat imagery. Geodetski vestnik 2008, Vol. 52, No. 3, 457-474.

Veljanovski, T., Lamovec, P., Pehani, P., Oštir, K. (2011a). Comparison of three techniques for detection of flooded areas on ENVISAT and RADARSAT-2 satellite images. In: Geoinformation for disaster management: Gi4DM 2011, 3.-8. May 2011, Antalya, Turkey.

Veljanovski, T., Pehani, P., Kokalj, Ž., Oštir, K. (2011b). Zaznavanje poplav s časovno vrsto radarskih satelitskih posnetkov ENVISAT in RADARSAT-2. In: Zorn, M., Komac, B., Ciglič, R., Pavšek, M. (Eds.): Neodgovorna odgovornost, (Naravne nesreče, 2). Ljubljana: ZaložbaZRC, 2011, pp. 81-89. http://giam.zrc-sazu.si/sites/default/files/Naravnenesrece-02.pdf (April 2011).

Whiteside, T. (2005). A multi-scale object-oriented approach to the classification of multi-sensor imagery for mapping land cover in the top end. In: Proceedings of NARGIS 2005 - Applications in Tropical Spatial Science. Charles Darwin University, Darwin, NT, Australia. 4.-7. July 2005.

Whiteside, T., Ahmad, W. (2005). A comparison of object-oriented and pixel-based classification methods for mapping 
land cover in northern Australia. Proceedings 2005. Melbourne: Spatial Sciences Institute.

Willhauck, G., Schneider, T., De Kok, R., Ammer, U. (2000). Comparison of object oriented classification techniques and standard image analysis for the use ofchange detection between SPOT multispectral satellite images and aerial photos. In: ISPRS, Vol. XXXIII, Amsterdam, 2000.

Yan, G., Mas, J.F., Maathuis, B.H.P., Xiangmin, Z., Van Dijk, P.M. (2006). Comparison of pixel-based and objectoriented image classification approaches-a case study in a coal fire area, Wuda, Inner Mongolia, China. International Journal of Remote Sensing. Vol.27, No.18., 4039-4055.

Z_GIS research and Innovation (2011). http://www.zgis.at/research (April 2011).

Prispelo v objavo: 13. maj 2011

Sprejeto: 7. november 2011

dr. Tatjana Veljanovski, univ. dipl. inž. geod.

ZRC SAZU, Inštitut za antropološke in prostorske študije, Novi trg 2, SI-1000 Ljubljana Center odličnosti Vesolje-SI, Aškerčeva 12, SI-1000 Ljubljana

e-pošta:tatjanav@zrc-sazu.si

Urša Kanjir, univ. dipl. inž. geod.

ZRC SAZU, Inštitut za antropološke in prostorske študije, Novi trg 2, SI-1000 Ljubljana e-pošta: ursa.kanjir@zrc-sazu.si

izr. prof. dr. Krištof Oštir, univ. dipl. inž. fiz.

ZRC SAZU, Inštitut za antropološke in prostorske študije, Novi trg 2, SI-1000 Ljubljana Center odličnosti Vesolje-SI, Aškerčeva 12, SI-1000 Ljubljana e-pošta:kristof@zrc-sazu.si, kristof.ostir@space.si 